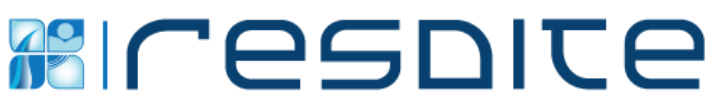

\section{Elaboração de protocolo para confecção de dispositivo corretivo ocular customizado impresso 3D para crianças acometidas com microcefalia}

\author{
Development of a $3 d$ printed custom corrective device protocol for microcephaly children
}

\author{
Diogo Pontes Costa', Nadja Maria da Silva Oliveira², Rafael Grotta Grempel ${ }^{3}$, José \\ Augusto de Oliveira Neto ${ }^{4}$
}

\begin{abstract}
Resumo
Objetivo: desenvolver um protocolo para materialização de armação de óculos para crianças com Microcefalia, sendo desenvolvido por meio de um software CAD (Projeto Auxiliado por Computador) de criação virtual de código aberto (OnShape) e obtido por Impressão tridimensional pelo processamento de Filament Deposition Modeling - FDM, utilizando o filamento de Poliuretano Termoplástico (TPU) como material. Método: Tratase de uma investigação aplicada e experimental. Resultado e discussão: Inicialmente, apresenta-se os principais temas para a fundamentação da proposta de projeto, as informações acerca das Tecnologias Assistivas e do desenvolvimento das tecnologias de manufatura aditiva aplicadas à saúde. Além disso, observa-se a descrição do procedimento adotado no projeto e a necessidade de uma revisão sistemática e do levantamento de dados antropométricos da cabeça das crianças. Ademais, houve a necessidade de desenvolvimento de uma coleta de dados com as medidas faciais antropométricas das crianças e submete-las à análise com intuído de extrair as médias e com isso criar um humanoide $3 D$ que foi utilizado como suporte no desenvolvimento da proposta, visto que assim, foi possível desenvolver alguns testes de interação com o dispositivo, antes mesmo de ser impresso tridimensionalmente. Então, após essa criação, foi possível partir para o desenvolvimento do dispositivo e criação do protocolo, que contou com o uso dos softwares livres de modelagem virtual, com a utilização das impressoras $3 D$, bem como com o processo de pós-acabamento. Posteriormente, foi realizado um teste para validação do protocolo da criação da armação com alguns projetistas, com intenção de melhorá-lo e mitigar as possíveis falhas. Por fim, o arquivo CAD da armação de óculo foi disponibilizado, gratuitamente, em plataformas digitais, a fim de serem utilizados em laboratórios da rede Sistema Único de Saúde (SUS). Conclusão: O desenvolvimento deste protocolo como recurso acessível aos profissionais do SUS para a criação de um modelo de armação de óculos impresso em 3D, sob preceito open-source, permite que haja um melhor entendimento do processo de produtos impressos, além da simplificação na prototipação do produto em questão. Podemos observar, ao longo do trabalho, uma série de produtos inovadores que atendem às demandas da população, contudo, este projeto, permite-se ir além do modelo impresso em $3 D$, pois compreendemos que os procedimentos aqui adotados, bem como os arquivos elaborados, apoiam a perspectiva de que os sistemas
\end{abstract}

\footnotetext{
1 Mestre pelo Programa Pós-Graduação Ciência e Tecnologia em Saúde (PPGCTS) pela Universidade Estadual da Paraíba (UEPB. E-mail: diogopontes12@gmail.com

2 Doutora em Ciência e Engenharia dos Materiais pela Universidade Federal de Campina Grande/UFCG. E-mail: nadjamso@gmail.com

3 Doutor em Cirurgia e Traumatologia Bucomaxilofacial pela Universidade de Campinas. Email: rafaelgrempel@gmail.com 4 Doutor em Ciência da Computação pela Universidade Federal de Campina Grande. Email: zedeguga@gmail.com Correspondência: Avenida Presidente Getúlio Vargas, 805 Ap.03 - CEP: 58.400-585. Campina Grande - Paraíba.
}

RE. SAÚD. DIGI. TEC. EDU., Fortaleza, CE, v.4, n.2, p.11-14, ago./dez. 2019. ISSN: 2525-9563 
CAD/CAM são acessíveis a qualquer indivíduo que se propusera estudá-los e desenvolvelos. Observou-se também o método adotado nesta pesquisa em consonância com os identificados na Revisão de Literatura e na Sistemática. Além disso, houve uma nova abordagem na pré-visualização da interação entre produto/usuário, possibilitando a diminuição de erros nas tomadas de decisões.

Palavras-Chave: Desenho Assistido por Computador. Sistema Único de Saúde. Impressão Tridimensional.

\section{Abstract}

Objective: To develop a protocol for the materialization of eyeglass frames for children with Microcephaly, being developed using a software CAD (Computer-aided Design) and obtained by three-dimensional printing by Filament Deposition Modeling processing (FDM) using Thermoplastic Polyurethane (TPU) filament as material. Method: This is an applied and experimental investigation. Results and discussion: First of all, we present the main themes for the project proposal, information about Assistive Technologies and the development of additive manufacturing technologies applied to health. Furthermore, there is the presence of the procedure to be adopted in the project and the indication of the need for a Systematic Review and anthropometric survey of the children's head. In addition, it was necessary to develop a data collection with the anthropometric facial measurements of the children and submit them to the analysis with the intention of extracting the averages and thus create a 3D humanoid that was used as support in the development of the proposals, since thus, it was possible to develop some interaction tests with the device, even before being printed three-dimensionally. Then, after this creation, it was possible to go to the device development and protocol creation, where it counted on the use of free virtual modeling software, the use of $3 D$ printers, as well as the post-finishing process. Subsequently, a test was carried out to validate the frame creation protocol with some designers, in order to improve it and mitigate possible failures. Finally, the eyepiece frame $C A D$ file was freely available on digital platforms in order to be used in laboratories of the Unified Health System (SUS). Conclusion: The development of this protocol as an accessible resource for SUS professionals, for the creation of a 3D printed glasses frame model, under open-source precept, allows a better understanding of the printed products process, besides simplifying the process of prototyping of the product concerned. We can observe, throughout the work, a series of innovative products that meet the demands of the population, however, this project allows us to go beyond the 3D printed model, because we understand that the procedures adopted here, as well as the elaborated files, support the view that CAD / CAM systems are accessible to anyone who proposes to study and develop them. It was also observed the method adopted in this research are in line with those identified in the Literature Review and Systematics. In addition, there was a new approach in previewing the interaction between product/user, enabling the reduction of errors in decision making.

Keywords: Computer-Aided Design. Unified Health System. Printing, Three-Dimensional.

\section{Agradecimentos}

Agradecemos à Universidade Estadual da Paraíba (UEPB), ao Programa de PósGraduação em Ciências e Tecnologias em Saúde (PPGCTS), ao Núcleo de Tecnologias em Saúde (NUTES) e à Coordenação de Aperfeiçoamento de Pessoal de Nível Superior (CAPES).

RE. SAÚD. DIGI. TEC. EDU., Fortaleza, CE, v.4, n.2, p.11-14, ago./dez. 2019. ISSN: 2525-9563 


\section{Obra original}

1. Costa DP. Elaboração de protocolo para confecção de dispositivo corretivo ocular customizado impresso 3D para crianças acometidas com microcefalia. UEPB, Campina Grande, 2019. Dissertação (Mestrado em Ciências e Tecnologia em Saúde) - Programa de Pós-Graduação em Ciências e Tecnologia em Saúde, Campina Grande, 2019. Disponível em: a partir de fevereiro de 2020 no repositório institucional da UEPB.

RE. SAÚD. DIGI. TEC. EDU., Fortaleza, CE, v.4, n.2, p.11-14, ago./dez. 2019. 


\section{Como citar este artigo}

Costa DP; Oliveira NMS; Grempel RG; Neto JAO. Elaboração de protocolo para confecção de dispositivo corretivo ocular customizado impresso 3D para crianças acometidas com microcefalia. Revista de Saúde Digital e Tecnologias Educacionais. [online], volume 4, n. 2. Editor responsável: Luiz Roberto de Oliveira. Fortaleza, mês e ano, p.11-14. Disponível em: http://periodicos.ufc.br/resdite/index. Acesso em "dia/mês/ano".

Data de recebimento do artigo: 01/10/2019

Data de aprovação do artigo: 25/11/2019

RE. SAÚD. DIGI. TEC. EDU., Fortaleza, CE, v.4, n.2, p.11-14, ago./dez. 2019. ISSN: 2525-9563 